\title{
Educação Profissional e evasão escolar em contexto: motivos e reflexões
}

\author{
Natália Gomes da Silva Figueiredo ${ }^{a}$ \\ Denise Medeiros Ribeiro Salles ${ }^{a}$
}

\section{Resumo}

Esta pesquisa teve por objetivo analisar as causas de evasão no primeiro período de um curso técnico do Cefet/RJ, unidade Petrópolis. Buscou não apenas identificar os fatores diretamente sinalizados pelos ex-alunos como causas do abandono, mas compreender as relações entre os diversos elementos presentes em seus discursos. A investigação, que envolveu pesquisa documental e de campo, assumiu a forma de um estudo de caso. No que diz respeito à abordagem, o estudo foi do tipo qualitativo e empregou a estratégia da análise de conteúdo para o tratamento do material, coletado por intermédio de entrevistas semiabertas. Os resultados da pesquisa apontaram causas de evasão relacionadas às seguintes categorias: lacunas na escolha do curso; fatores escolares; dificuldades pessoais; influência de amigos; oportunidades e desinteresse institucional e/ou governamental.

Palavras-chave: Educação profissional. Curso técnico. Evasão.

\section{Introdução}

A Educação Profissional Técnica, historicamente associada às concepções e modelos econômicos vigentes e às demandas por eles geradas no contexto do mercado de trabalho, tem estado cada vez mais no centro das atenções. Governos e empresários constituem alianças no sentido de criar e manter cursos que, de alguma forma, possam suprir postos estratégicos para o desenvolvimento do país, contribuindo, igualmente, para a elevação do nível de escolarização dos trabalhadores.

A expansão da Rede de Educação Profissional e Tecnológica, ação governamental que se iniciou em 2003, reflete esse posicionamento. A criação de novas unidades de ensino, com cursos adaptados às necessidades de desenvolvimento local e

a Universidade Federal Fluminense. Niterói, Rio de Janeiro, Brasil.

Recebido em: 29 abr. 2015

Aceito em: 14 jun. 2016 
regional, visa atender às demandas de qualificação dos trabalhadores da nova economia, além de fomentar o avanço da produção científica na área.

Vale destacar que as iniciativas do governo, no que diz respeito aos investimentos em Educação Profissional, têm alcançado visibilidade não apenas em território nacional. O documento "Centenário da Rede Federal de Educação Profissional e Tecnológica", disponibilizado no site do Ministério da Educação (MEC), comemorativo do centenário da Rede, faz referência a projetos de intercâmbio internacional e enfatiza o interesse de países africanos em desenvolver parcerias educacionais com o Brasil, que se tornou referência pelas experiências desenvolvidas (BRASIL, 2016).

No entanto, embora as perspectivas sejam otimistas, é preciso avaliar o contexto no qual se dão essas ações, bem como refletir sobre o real impacto delas no itinerário formativo e profissional dos estudantes. Indicadores de retenção, evasão discente, formação de professores, bem como os relacionados à infraestrutura das escolas, podem fornecer informações relevantes às pesquisas que visam avaliar a eficiência e a eficácia desses programas governamentais.

É importante destacar, entretanto, que esses indicadores, geralmente associados a dados quantificáveis, não permitem a abordagem da realidade social mais complexa. Eles apenas possibilitam uma análise de cunho instrumental, que avalia resultados, muitas vezes vagos ou superficiais, cuja tendência é camuflar aspectos importantes do objeto de estudo.

Este trabalho faz uma análise qualitativa do fenômeno da evasão no âmbito da Educação Profissional Técnica de Nível Médio e se insere no contexto das iniciativas que visam não apenas compreender os fatores que motivam os alunos a deixarem seus cursos, bem como busca contribuir com as discussões referentes às políticas desenvolvidas para essa modalidade de educação.

\section{Revisão da literatura}

Quando se trata de evasão, a literatura apresenta um quadro conceitual bastante diverso, com definições que nem sempre dialogam entre si, gerando ambiguidade e/ou limitação às análises. Conforme Dore e Lüscher (2011, p. 775),

A evasão escolar tem sido associada a situações tão diversas quanto a retenção e repetência do aluno na escola, a saída do aluno da instituição, a saída do aluno do sistema de ensino, a não conclusão 
de um determinado nível de ensino, o abandono da escola e posterior retorno. Refere-se ainda àqueles indivíduos que nunca ingressaram em um determinado nível de ensino, especialmente na educação compulsória, e ao estudante que concluiu um determinado nível de ensino, mas se comporta como um dropout.

Uma definição bastante abrangente e recorrente nas produções é a de Gaioso (2005, apud BAGGI; LOPES, 2011, p. 356), que caracteriza a evasão como "um fenômeno social complexo, definido como interrupção no ciclo de estudos".

Para Johann (2012, p. 65),

a evasão é um fenômeno caracterizado pelo abandono do curso, rompendo com o vínculo jurídico estabelecido, não renovando o compromisso ou sua manifestação de continuar no estabelecimento de ensino. Esta situação de evasão é vista como abandono, sem intenção de voltar, uma vez que não renovando a matrícula rompe-se o vínculo existente entre aluno e escola.

No material produzido pela Comissão Especial de Estudos Sobre a Evasão nas Universidades Públicas Brasileiras, designada pelo MEC, há o reconhecimento da não unanimidade em relação ao conceito de evasão, seguido da recomendação de que a opção por esta ou aquela definição esteja em consonância com o objeto particular de estudo, o que evitaria o risco de generalizações ou simplificações (COMISSÃO ESPECIAL DE ESTUDOS..., 1996, p. 19). O referido documento distingue três tipos de evasão, dada a realidade do Ensino Superior:

- Evasão de curso: quando o estudante desliga-se do curso superior em situações diversas tais como: abandono (deixa de matricular-se), desistência (oficial), transferência ou reopção (mudança de curso), exclusão por norma institucional;

- Evasão da instituição: quando o estudante desliga-se da instituição na qual está matriculado;

- Evasão do sistema: quanto o estudante abandona de forma definitiva ou temporária o ensino superior (COMISSÃO ESPECIAL DE ESTUDOS..., 1996, p. 20).

A opção realizada pela Comissão, em seu estudo, define evasão como "a saída definitiva do aluno de seu curso de origem, sem concluí-lo" (COMISSÃO 
ESPECIAL DE ESTUDOS..., 1996, p. 19). Um dos argumentos que justificam a escolha diz respeito à "inexistência, em nível nacional, de conjunto de dados relativos ao destino dos evadidos dos diferentes cursos" (COMISSÃO ESPECIAL DE ESTUDOS..., 1996, p. 19), o que dificultaria, por exemplo, a obtenção de informações sobre mobilidade dos estudantes.

O Dicionário de Indicadores do Instituto Nacional de Estudos e Pesquisas Educacionais Anísio Teixeira (INEP), em uma definição bastante funcional, refere-se a alunos evadidos como "alunos que estando matriculados na série $s$ no ano $m$ não encontram-se na matrícula da série $s$ ou $s+1$ no ano $m+1$ " (BRASIL, 2004, p. 19). Embora precisa e, portanto, facilitadora dos levantamentos, sobretudo quantitativos, relacionados à temática, tal definição parece não abranger, adequadamente, a Educação Profissional, modalidade de ensino não obrigatória, com diversos cursos de organização semestral, como o abordado por este estudo.

Portanto, pela adequação ao objeto de estudo, bem como aos objetivos propostos, o conceito de evasão adotado pelas autoras dessa pesquisa é o da Comissão Especial de Estudos Sobre a Evasão nas Universidades Públicas Brasileiras, a saber: evasão como "saída definitiva do aluno de seu curso de origem, sem concluí-lo" (COMISSÃO ESPECIAL DE ESTUDOS..., 1996, p. 19). Tendo em vista que essa saída pode se dar de diversas maneiras, torna-se necessário esclarecer que o estudo considerou: os casos expressos de abandono sem retorno registrados como tal na Secretaria Acadêmica da Unidade, os casos de cancelamento de matrícula, e também os casos de alunos reprovados ou jubilados por infrequência, que terminaram por caracterizar a mesma situação de abandono sem retorno, ao menos dentro do período compreendido pela análise.

É importante ressaltar, em uma análise mais ampla, outros aspectos relacionados às discussões que buscam situar o campo de estudos da evasão. De acordo com Machado e Moreira (2012, p. 2), estando a evasão relacionada aos fatores que motivam os estudantes a não permanecer nos estudos, ela se constitui, sobretudo, de uma questão vinculada ao próprio processo de democratização do ensino profissionalizante no país. Outra forma de análise, apontada pelas pesquisadoras, seria abordar a evasão do ponto de vista da exclusão. Por ambas as perspectivas, tem se tornado claro que as investigações precisam ser aprofundadas.

Ao contrário do que ocorre nos níveis fundamental e médio, o ensino técnico não conta com uma quantidade expressiva de estudos sobre evasão, o que dificulta tanto a construção de um referencial teórico sólido quanto o levantamento de 
indicadores a serem utilizados nas pesquisas empíricas (DORE; LÜSCHER, 2011; MACHADO; MOREIRA, 2012; SALES; CASTRO; DORE, 2013).

Além das dificuldades inerentes à oferta reduzida de estudos, podem instituir-se as de caráter conceitual. É importante considerar que, além de fazer referência a diversas situações, como referido anteriormente, a evasão pode ser abordada do ponto de vista de diferentes atores e a partir de níveis distintos de ensino. Nas palavras de Sales, Castro e Dore (2013, p. 6), trata-se de um “[...] fenômeno complexo, multifacetado e multicausal, atrelado a fatores pessoais, sociais e institucionais [...]".

Três dimensões conceituais têm sido consideradas importantes nos estudos sobre evasão:

1) Níveis de escolaridade em que ela ocorre, como a educação obrigatória, a educação média ou a superior; 2) Tipos de evasão, como a descontinuidade, o retorno, a não conclusão definitiva, dentre outras; 3) Razões que motivam a evasão, por exemplo, a escolha de outra escola, um trabalho, o desinteresse pela continuidade de estudos, problemas na escola, problemas pessoais ou problemas sociais (DORE; LÜSCHER, 2011, p. 775).

Acrescenta-se a essas dimensões a questão da perspectiva adotada na investigação do problema, que pode ser a do indivíduo, a da escola ou a do sistema de ensino (DORE; LÜSCHER, 2011, p. 775). É importante ressaltar que a ótica sob a qual se investiga o fenômeno pode alterar significativamente os resultados da pesquisa, uma vez que diferentes atores atribuem diferentes significados às experiências. Isso demanda um cuidado especial por parte do pesquisador, que deve estar atento à coerência entre os objetivos estabelecidos e o percurso definido.

Dentre as concepções identificadas na literatura a respeito de evasão, é interessante enfatizar o entendimento de que o abandono escolar constitui a última etapa de um processo dinâmico e cumulativo de desengajamento do estudante da vida escolar (RUMBERGER, 1995). Nos Estados Unidos, essa premissa tem pautado o desenvolvimento de diversos modelos que buscam antecipar-se ao problema, identificando o risco de evasão associado a fatores de toda ordem (BOWERS; SPROTT, 2012; FALL; ROBERTS, 2012; RUMBERGER, 1995).

No que diz respeito à dimensão conceitual que busca analisar as razões que motivam a evasão, é imprescindível fazer duas observações importantes. A primeira tem 
relação com a urgência desse tipo de levantamento. Sendo a evasão um problema que apresenta consequências não apenas para os próprios indivíduos evadidos, mas para a sociedade como um todo, deve ser interesse coletivo combatê-la, o que só pode ser feito, primeiramente, por intermédio do esforço de compreensão de suas causas. Grande parte das pesquisas realizadas nos Estados Unidos a respeito de abandono escolar se dá sob esse enfoque (RUMBERGER, 1995, p. 585).

A segunda observação remete à complexidade associada aos levantamentos que buscam identificar causas de evasão. Essa complexidade envolve, pelo menos, três fatores: a propensão dos alunos evadidos a não responder as pesquisas (MURNANE, 2013, p. 8) que, muitas vezes, está associada à própria dificuldade de localizá-los e ao constrangimento ocasionado pela situação (SILVA; DORE, 2011, p. 89); a falta de precisão das respostas, por vezes inconsciente, as quais nem sempre remetem à verdadeira causa do problema (FREDENHAGEM et al., 2012); e as deficiências inerentes às bases de dados (SALES; CASTRO; DORE, 2013).

A seção a seguir reúne causas de evasão apresentadas em estudos de âmbito nacional e internacional. Haja vista não serem muitos os estudos sobre abandono escolar associados ao ensino técnico, optou-se por realizar o levantamento em material referente, principalmente, ao Ensino Médio e, em tópico distinto, tratar o material específico. Alguns estudos que tratam do assunto sem especificações de nível também foram contemplados. É importante ressaltar, a esse respeito, que essa também foi a solução adotada por Dore e Lüscher (2011) ao selecionarem o conjunto de indicadores para a construção de seus instrumentos de coleta de dados utilizados na pesquisa sobre permanência e evasão na educação técnica de nível médio em Minas Gerais.

\subsection{Fatores motivadores de evasão}

Embora a busca por soluções para a problemática da evasão passe, necessariamente, pela investigação de suas causas, um levantamento desse tipo pode ser algo extremamente desafiador. Rumberger (2011) afirma que uma grande variedade de fatores, dentre eles os relacionados à escola, família e trabalho, pode contribuir para o fenômeno da evasão e a interação entre esses fatores ao longo do tempo torna praticamente impossível demonstrar uma relação causal entre um fator isolado e a decisão de abandonar a escola.

No entanto, o referido autor aponta que uma série de estudos empíricos, oriundos de disciplinas das Ciências Sociais, tem distinguido dois tipos de fatores: os individuais, relacionados aos próprios alunos, suas atitudes, comportamentos, 
desempenho escolar e experiências anteriores; e os contextuais, que se associam às famílias dos estudantes, às escolas e às comunidades em que vivem.

No tocante aos fatores individuais, o autor prossegue sua análise afirmando que as taxas de abandono são mais elevadas entre os alunos pouco motivados em termos educacionais e ocupacionais. Outros fatores como absenteísmo, mau comportamento, gravidez e desempenho escolar insatisfatório também entram na relação. Uma observação interessante relativa a esses fatores diz respeito à sua vinculação com o contexto em que vive o estudante. De acordo com paradigma sustentado pela Psicologia do Desenvolvimento, aspectos referentes às famílias, escolas e comunidades moldam atitudes, comportamentos e experiências.

Do ponto de vista dos fatores contextuais, o autor concede destaque às famílias. A condição socioeconômica, geralmente medida por índices de renda familiar e escolaridade dos pais, pode incidir significativamente sobre o desempenho e comportamento do estudante, determinando desde suas aspirações e o quanto ele vai obter de apoio, até os serviços de que vai dispor na busca por uma aprendizagem mais eficaz. O autor chama a atenção também para a estrutura familiar. Quando filho adotivo ou oriundo de família monoparental, o estudante tem mais probabilidade de fracassar.

Ainda segundo Rumberger (2011), outros dois fatores podem ser enquadrados na perspectiva que analisa a influência do contexto sobre a probabilidade de abandono: a escola e as comunidades e grupos de amigos. Na análise da influência escolar, quatro características são ressaltadas: composição do corpo discente; características estruturais; recursos escolares e políticas e práticas. Sobre as comunidades e grupos de amigos, o autor chama atenção para as diferenças nas características dos bairros que podem ajudar a explicar os contrastes nas taxas de evasão e ressalta o fato de que estudantes que vivem em comunidades pobres tendem a ter desistentes como amigos, o que aumenta a probabilidade de também tornarem-se evadidos.

Outros autores também refletiram acerca dos fatores escolares e sobre a influência de amigos no processo de evasão. Lee e Burkam (2003) demonstraram que as escolas, por intermédio de sua estrutura e da maneira como se organizam acadêmica e socialmente, podem exercer grande influência sobre a decisão dos estudantes de permanecerem ou abandonarem os estudos. Em termos de estrutura da escola, os autores destacaram aspectos como tamanho e forma de controle (pública, privada ou Católica). No tocante aos elementos organizacionais, ressaltaram o papel do currículo e das relações entre professores e alunos. 
Dentre os resultados de Lee e Burkam (2003), destaca-se o fato de que os alunos são menos propensos à evasão nas escolas de pequeno porte e nas instituições em que os cursos acadêmicos suplantam os não acadêmicos. Além disso, estudantes tendem a permanecer quando as relações que mantêm com os professores são positivas. Entretanto, conforme colocado pelos autores, o impacto das relações positivas depende das características organizacionais e estruturais da escola. Em suma, é possível afirmar que nenhum dos fatores age isoladamente. Segundo Lee e Burkam (2003), características estruturais e organizacionais tendem a interagir na tomada de decisão do aluno de abandonar a escola.

Outro elemento demasiadamente relevante em termos de atuação escolar e com alto impacto sobre a evasão diz respeito às práticas de avaliação, por vezes classificatórias e excludentes. Hoffmann (2013), muito referenciada em estudos da área, denuncia o uso abusivo das notas pelos docentes e afirma que isso implica no reducionismo do significado da avaliação. A autora defende uma prática avaliativa que seja pautada no princípio da investigação, permitindo ao educador, realizar o acompanhamento do aluno ao longo do tempo.

Ainda sobre o impacto dos fatores escolares, é importante mencionar a pesquisa de Marin (1998). A autora apresenta um panorama das condições de trabalho dos docentes nas escolas públicas e lista elementos que considera como desafios fundamentais a serem superados. Dentre eles, dada a sua relevância para o desenvolvimento desta pesquisa, destacam-se:

- Fragilidade, rigidez e restrição nos procedimentos e recursos didáticos, com destaque para a escolha e a utilização do livro didático;

- Inalteração nos baixos níveis de aproveitamento escolar dos alunos;

- Conflitos e dilemas enfrentados pelos professores no que se refere à relação entre seu saber fazer e as características dos alunos "fracos" e/ou das camadas populares;

- Indisciplina na sala de aula;

- Dificuldades no processo de reflexão e raciocínio dos professores e seus desdobramentos para a concretização das práticas educativas;

- Referencial restrito dos professores em relação a experiências bem-sucedidas, sejam de ensino, sejam de escolas (MARIN, 1998, p. 15). 
Por fim, analisando o impacto da Reforma do Ensino Profissional na educação tecnológica ministrada pelo Cefet-X, Oliveira (2001) relaciona causas de evasão apontadas em um evento promovido pela Instituição, a saber: dificuldades discentes relativas ao acompanhamento das disciplinas de cunho profissional; interesse insuficiente, por parte de alguns docentes, no auxílio a estudantes em situação de defasagem; frustrações dos alunos no que tange aos Cursos Técnicos, dificuldades de conciliar os horários do Ensino Médio com os do Curso Técnico, o que ocorre na modalidade de concomitância externa, e razões financeiras.

Sobre a influência de amigos, destaca-se o estudo desenvolvido por Carbonaro e Workman (2013). Ao analisar os efeitos das amizades próximas e distantes sobre o comportamento de evasão no Ensino Médio, os autores chegaram a uma interessante conclusão: os amigos distantes tendem a exercer maior influência sobre os estudantes. Segundo Carbonaro e Workman (2013), isso se explica pelas referências que pautam essas distintas relações de amizade. A identidade social dos alunos e sua convicção sobre aquilo que é "normativo" encontra respaldo nos amigos distantes, a respeito dos quais os estudantes não têm muitas referências, ao passo que o comportamento dos amigos próximos, na visão dos estudantes, tem relação com suas características de personalidade e com as circunstâncias em que vivem.

Stearns e Glennie (2006) analisaram as causas de evasão a partir das diferenças de idade, série, gênero e etnia. As autoras fizeram uso de teorias que distinguem dois tipos de fatores de evasão: os pull-out e os push-out. O primeiro representa o grupo de fatores de evasão externos às escolas, tais como família e oportunidades de emprego. Esses fatores, que atraem os estudantes para fora das escolas, incidem de maneira distinta sobre os alunos. De acordo com as autoras, estudantes do sexo feminino e estudantes não pertencentes à raça branca têm maior tendência a deixar a escola por responsabilidades familiares, ao passo que estudantes do sexo masculino, em especial os mais velhos, tendem a abandonar os estudos por razões de emprego.

Os fatores push-out, por sua vez, dizem respeito aos elementos escolares que desestimulam os alunos a prosseguirem com seus estudos. Envolvem, por exemplo, questões relativas à estrutura e às políticas escolares. Segundo Stearns e Glennie (2006), estudantes do sexo masculino, bem como os mais jovens, são mais propensos a deixarem a escola por razões disciplinares. No que diz respeito à etapa de ensino, as autoras destacam que os maiores índices de evasão se encontram entre estudantes da nona série, padrão que persiste para os indivíduos do sexo masculino e entre os negros, latinos e americanos nativos. 
Outro grupo de fatores foi mencionado na pesquisa de Doll, Eslami e Walters (2013): falling out. O grupo identifica elementos relacionados à dificuldade dos estudantes em demonstrarem progresso acadêmico significativo, o que resulta em apatia ou desilusão a respeito da possibilidade de conclusão dos estudos. Conforme elucidado pelos autores, não se trata de uma decisão ativa do estudante. Falling out constitui o efeito da insuficiência de apoio pessoal e educacional. Trata-se de um processo de abandono em que o aluno gradualmente manifesta desejos e comportamento de desengajamento. Aqui não há "agente motivador" da evasão. Nem escola, nem aluno são responsáveis por esse tipo de fracasso, mas circunstâncias.

A pesquisa desenvolvida por Doll, Eslami e Walters teve por objetivo realizar uma análise comparativa entre sete estudos com representatividade nacional para determinar quais seriam os fatores de maior impacto sobre a evasão: pull-out, push-out ou falling out. Os resultados demonstraram que, ao contrário do que historicamente as pesquisas costumavam apontar, são os elementos push-out $\mathrm{e}$ não os pull-out que têm exercido maior influência sobre a decisão dos alunos de abandonarem a escola.

Trazendo a discussão acerca dos motivos da evasão escolar para o âmbito das pesquisas nacionais, é possível avaliar o contexto no qual essa pesquisa se insere. Neri (2010) fundamenta-se em um modelo de decisões baseado em capital humano ${ }^{1}$ para explicar as motivações dos "sem escola". De acordo com o autor,

[...] não basta enxergar as boas propriedades da política educacional, como o potencial de equidade e de retorno privado ou social exercido. É preciso entender como as informações chegam às pessoas e como elas transformam as informações recebidas em decisões (NERI, 2010, p. 21).

O autor aplica o modelo à decisão de escolaridade na adolescência e afirma que os pais ou os próprios estudantes têm que escolher a respeito da frequência à escola ou ao trabalho ou, ainda, a ambos. A decisão requer ponderação sobre "custo de oportunidade trabalhista presente do tempo da criança versus o valor que se pode antecipar em relação ao novo fluxo de rendimentos futuros que decorrerão da acumulação de mais capital humano" (NERI, 2010, p. 24). Ainda segundo o autor, se os pais enfrentam dificuldades relativas a restrições de renda, a trajetória

"[...] conjunto de habilidades e conhecimentos que se acumulam e aumentam a capacidade do indivíduo de desempenhar funções laborais" (NERI, 2010, p. 23). 
de longo prazo prevista pelo modelo poderá sofrer desvios, já que esse tipo de restrição aumenta a probabilidade de abandono escolar.

Neri (2010) toma como base os microdados da Pesquisa Nacional por Amostra de Domicílios (PNAD) 2006/IBGE para mostrar a evolução da frequência à escola e das taxas de trabalho da primeira infância até os 30 anos de idade. De acordo com a análise, aos 13 anos de idade, $97 \%$ dos pesquisados frequentam a escola e 10\% trabalham. Aos 18 anos, a taxa de frequência escolar passa a ser de 53\% e a de trabalho $54 \%$. Aos 30 anos, enquanto $10 \%$ dos pesquisados estudam, $74 \%$ trabalham.

Uma extensa análise dos benefícios decorrentes de uma maior escolaridade é realizada por Neri (2010). O autor investiga o impacto da decisão de frequentar ou não a escola sobre as possibilidades de inserção trabalhista do indivíduo e sobre a geração de renda. Além das variáveis econômicas, às quais ele concede destaque, o autor faz menção aos efeitos da escolaridade sobre a saúde percebida dos indivíduos e lança o seguinte questionamento: "Se a educação gera um retorno privado tão alto, por que os brasileiros investem tão pouco nela?" (NERI, 2010, p. 33).

A partir dos suplementos de educação da Pesquisa Nacional por Amostra de Domicílios (PNAD) de 2004 e 2006, Neri (2010) identifica quatro grandes grupos de fatores que motivam evasão até os 17 anos de idade: dificuldade de acesso à escola, que responde por $10,9 \%$ dos abandonos; necessidade de trabalho e geração de renda, associado à $27,1 \%$ das evasões; falta intrínseca de interesse, responsável pelo abandono de $40,3 \%$ dos alunos; e outros motivos, expressos na taxa de $21,7 \%$. A respeito da elevada proporção de estudantes que deixaram de frequentar a escola por motivo de "falta de interesse", o autor argumenta que, talvez, isso ocorra em função do "desconhecimento dos potenciais prêmios oferecidos pela educação” (NERI, 2010, p. 36).

Essa visão é criticamente analisada por Setúbal (2010). Segundo a autora, "falta de interesse" remete a uma ideia ampla e vaga, que deve ser observada a partir de significados que extrapolam a simples falta de informação. Setúbal (2010) propõe a discussão de outros aspectos que circundam a realidade de nossos estudantes, o que implica, necessariamente, reflexão acerca do cenário de marginalidade social e econômica em que boa parte deles vive. A pesquisadora menciona elementos como trabalho precário, tráfico de drogas, energia elétrica clandestina, terrenos sem documentação e outros que, tomados do ponto de vista do desempenho escolar, vão contribuir para a produção do fracasso. 
É importante ressaltar a forte atuação da escola na produção desse fracasso, que Setúbal (2010, p. 357-358) exprimiu da seguinte forma:

Nesse caleidoscópio da sociedade contemporânea, instala-se na escola uma violência simbólica, muitas vezes camuflada, perpassando as interações sociais ali construídas por meio de diferentes atitudes e regras invisíveis. Alguns exemplos: criação de obstáculos ao acolhimento de alunos que retornam à escola, geralmente oriundos de famílias de alta vulnerabilidade; distância entre o currículo formal e a realidade do mundo desses discentes; desvalorização da história e das vivências desses alunos e de suas famílias; culpabilização da família pelo malogro escolar dos filhos; dificuldade da escola em aceitar e lidar com a diversidade, a diferença e o preconceito. Essas atitudes, embora de difícil medição, são muitas vezes determinantes nos baixos resultados de aprendizagem e na evasão e abandono da escola. De um lado, escolas não conhecem o território do seu entorno e as condições socioculturais dos seus alunos, assumindo posições preconceituosas e desistindo do papel de garantir a aprendizagem de todos os discentes. Assiste-se à própria instituição de ensino atuar como legitimadora da evasão, como se abandonar a escola fosse "um bom negócio", uma vez que permitiria que o jovem trabalhasse e melhorasse a condição social da família. De outro lado, encontram-se pais que não têm modelo de referência de como apoiar os filhos na sua trajetória escolar, sentindo-se distantes e excluídos da escola de seus filhos.

Outros autores compartilharam visões semelhantes. Em suas ponderações acerca da evasão enquanto reflexo do sistema capitalista, Fornari (2010) afirma que ela é um fenômeno decorrente de dois fatores: organização escolar, que inclui a maneira como os professores se portam diante do aluno e sua história de vida, e herança cultural, social e econômica, que, em última instância, condiciona o desempenho intelectual do aluno. A autora sugere que a busca de soluções para a evasão, bem como para diversas outras problemáticas que caracterizam nosso sistema educacional, passa, antes de tudo, pela superação das formas de organização social e econômica pautadas no capitalismo, que encontram na escola uma via de reprodução e manutenção de relações contraditórias.

Para Costa (2000, p. 13), "a evasão é, sobretudo, um gesto de resistência ao discurso pedagógico, para além das causas concretas que a explicam [...]". A partir da análise dos resultados de sua pesquisa, a autora ressalta a contradição 
existente na problemática da evasão, que aponta para o fato de a escola pretender ser democrática, garantindo o acesso de todos à educação e, simultaneamente, não assumir sua identidade de espaço efetivamente público, deixando de suprir, em virtude disso, as necessidades do trabalhador no que diz respeito aos saberes escolares.

No que tange à especificidade da evasão na Educação Profissional, a literatura ainda é reduzida. No entanto, verifica-se um esforço, por parte de alguns autores, de fazer emergir no meio acadêmico pesquisas a esse respeito, estimuladas, em parte, pelo processo de expansão desse tipo de formação no país. Dentre esses esforços, destaca-se o de Rosemary Dore, autora de diversos trabalhos (DORE; LÜSCHER, 2011; SALES; CASTRO; DORE, 2013; SILVA; DORE, 2011) sobre permanência e evasão na educação técnica de nível médio em Minas Gerais. A autora, com apoio da Capes e do CNPq, coordena o projeto intitulado "Educação Profissional no Brasil e evasão escolar”, cujos objetivos são:

[...] integrar um grupo de pesquisa internacional que se organizou para pesquisar a educação profissional e o problema da evasão escolar entre jovens de 15 a 20 anos, nos países participantes; identificar e quantificar a evasão escolar no Brasil a partir de 1996, nos cursos de formação profissional, na faixa etária de 15 a 20 anos, bem como as suas causas, classificando-as de acordo com o contexto mais amplo das diferenças nacionais; cooperar na realização de estudos comparativos entre os dados da evasão no Brasil e aqueles dos demais países integrantes do grupo de pesquisa internacional; desenvolver, em comum com os países participantes, proposições que possam subsidiar a formulação de políticas educacionais para a educação profissional, com o intento de reduzir o número de jovens que abandonam esse tipo de ensino (INEP, 2014).

Em Silva e Dore (2011) identificam-se fatores de evasão relativos ao Programa de Educação Profissional de Minas Gerais (PEP-MG). Por intermédio desse programa, o governo do Estado realiza a compra de vagas em escolas da rede privada e as destina às seguintes categorias de estudantes: matriculados no $2^{\circ} \mathrm{ou}$ $3^{\circ}$ ano do Ensino Médio de escolas públicas estaduais; matriculados na Educação de Jovens e Adultos (EJA), correspondente ao Ensino Médio e na modalidade presencial; e concluintes do Ensino Médio, oriundos tanto da rede pública quanto da privada e que não estejam cursando o Ensino Superior. 
Embora o instrumento de pesquisa utilizado pelo PEP-MG para monitorar as causas de evasão dos cursos seja limitado por conter fatores imprecisos (SILVA; DORE, 2011) e por restringir-se à ótica individual no tratamento do problema, deixando de contemplar elementos institucionais e sociais (DORE; LÜSCHER, 2011), é possível afirmar que os resultados oriundos dessa investigação constituem material relevante para pesquisas a respeito do tema, visto que, conforme assinalado por Dore e Lüscher (2011), tratam-se das únicas indicações precisas a que tiveram acesso.

A Tabela registra os motivos de evasão apontados pelo Programa. Segundo os dados recolhidos, os alunos deixam a escola, em primeiro lugar, por motivos de emprego (36,56\%). Em seguida, destaca-se a proporção de discentes (20,91\%) que não fornecem qualquer justificativa para o abandono. Obviamente, como sinalizado por Dore e Lüscher (2011, p. 784), "é uma frequência muito alta para uma razão tão imprecisa”.

Ainda no âmbito da Educação Profissional, foram identificados outros trabalhos que tiveram por objetivo analisar causas de evasão. O Quadro 1 compila alguns dados importantes apresentados por esses autores.

Tabela. Causas de evasão no PEP.

\begin{tabular}{lc}
\hline Causas do Abandono (PEP) & $\%$ \\
\hline 1. Emprego & 36,56 \\
2. Desistente sem justificativa & 20,91 \\
3. Horário incompatível & 9,15 \\
4. Estudos & 8,91 \\
5. Ingresso no curso superior & 7,40 \\
6. Mudança de município & 4,23 \\
7. Saúde & 3,01 \\
8. Transporte & 2,95 \\
9. Gravidez & 1,85 \\
10. Achou muito difícil & 1,85 \\
11. Não se identificou com o curso & 1,75 \\
12. Filhos & 1,43 \\
\hline
\end{tabular}

Fonte: SEE-MG (2009) apud Sales, Castro e Dore (2013, p. 5). 
Quadro 1. Motivações para abandono escolar na Educação Profissional.

\begin{tabular}{|c|c|c|}
\hline Autor(a) & Proposta & Fatores de abandono \\
\hline $\begin{array}{l}\text { Araújo } \\
(2012)\end{array}$ & \begin{tabular}{|c|} 
Investigar as causas de evasão, \\
durante o período de 2007 a 2010, \\
no curso técnico integrado de \\
Química de Alimentos do Instituto \\
Federal de Educação, Ciência e \\
Tecnologia do Maranhão (campus \\
Monte Castelo/ São Luís), ofertado \\
pelo Programa Nacional de \\
Integração da Educação Profissional \\
com a Educação Básica na \\
Modalidade de Educação de Jovens \\
e Adultos (Proeja).
\end{tabular} & $\begin{array}{l}\text { Coincidência com horário de trabalho, } \\
\text { ausência de relação entre o currículo } \\
\text { e as expectativas do discente, falta de } \\
\text { afinidade, falta de conhecimento base, } \\
\text { falta de professor, custeio de transporte } \\
\text { e o fato de alguns alunos já possuírem o } \\
\text { Ensino Médio. }\end{array}$ \\
\hline $\begin{array}{l}\text { Azevedo e } \\
\text { Lima (2011) }\end{array}$ & $\begin{array}{l}\text { Abordar a evasão escolar no } \\
\text { âmbito do Proeja, implantado } \\
\text { no Centro Federal de Educação } \\
\text { Tecnológica de Mato Grosso } \\
\text { (Cefet-MT) em outubro de } 2007 .\end{array}$ & $\begin{array}{c}\text { Trabalho (incluindo o doméstico), família e } \\
\text { deficit de cultura escolar. }\end{array}$ \\
\hline Cravo (2012) & \begin{tabular}{|c|} 
Investigar as causas de evasão no \\
curso técnico de Informática de \\
uma faculdade de tecnologia de \\
Florianópolis.
\end{tabular} & $\begin{array}{c}\text { Não identificação com o curso, } \\
\text { horário incompatível, dificuldades de } \\
\text { aprendizagem, mudança de curso, } \\
\text { mudança de cidade, doença e outros. }\end{array}$ \\
\hline $\begin{array}{l}\text { Machado } \\
\text { (2009) }\end{array}$ & $\begin{array}{c}\text { Analisar os fatores motivadores } \\
\text { de evasão nos cursos de } \\
\text { Agropecuária e Informática da } \\
\text { Escola Agrotécnica Federal de } \\
\text { Inconfidentes - Minas Gerais, } \\
\text { abrangendo o período de } 2002 \\
\text { a } 2006 .\end{array}$ & $\begin{array}{l}\text { Afastamento da família, não identificação } \\
\text { com o curso escolhido, drogas, excesso de } \\
\text { atividades propostas pela escola, dificuldades } \\
\text { relativas ao processo ensino-aprendizagem, } \\
\text { desmotivação, deficiência na formação } \\
\text { escolar, distanciamento cultural entre } \\
\text { escola e aluno, práticas pedagógicas e } \\
\text { aspectos institucionais. }\end{array}$ \\
\hline $\begin{array}{l}\text { Marconatto } \\
\text { (2009) }\end{array}$ & \begin{tabular}{|c|} 
Pesquisar aspectos da evasão \\
escolar no Curso Técnico Agrícola \\
(modalidade EJA) da Escola \\
Agrotécnica Federal de Rio do \\
Sul - Santa Catarina. \\
\end{tabular} & $\begin{array}{l}\text { Dificuldade em conciliar horário de estudo } \\
\text { com o trabalho, desejo ou necessidade } \\
\text { de trabalhar e dificuldade de adaptação } \\
\text { à escola. }\end{array}$ \\
\hline $\begin{array}{l}\text { Moreira } \\
\text { (2012) }\end{array}$ & $\begin{array}{c}\text { Identificar fatores que } \\
\text { influenciam a evasão escolar } \\
\text { nos cursos técnicos do Proeja } \\
\text { na Rede Federal de Educação } \\
\text { Profissional e Tecnológica de } \\
\text { Minas Gerais. }\end{array}$ & $\begin{array}{l}\text { Dificuldade de conciliar o horário de } \\
\text { estudo e trabalho, necessidade de } \\
\text { trabalhar, o fato de a escola ser distante } \\
\text { de casa e/ou do trabalho, dificuldades } \\
\text { financeiras, falta de motivação para } \\
\text { continuar os estudos, falta de flexibilidade } \\
\text { nos horários para cursar as matérias, } \\
\text { excesso de matérias no curso e } \\
\text { professores muito exigentes. } \\
\end{array}$ \\
\hline $\begin{array}{l}\text { Silva, } \\
\text { Pelissari e } \\
\text { Steimbach } \\
(2013)\end{array}$ & $\begin{array}{c}\text { Discutir as razões de } \\
\text { permanência e abandono na } \\
\text { educação profissional técnica de } \\
\text { nível médio. }\end{array}$ & $\begin{array}{l}\text { Preferência pelo ensino médio regular, } \\
\text { falta de gosto pelo curso e dificuldade nas } \\
\text { disciplinas. }\end{array}$ \\
\hline
\end{tabular}

Fonte: Autoria própria (2014). 
Acrescenta-se ainda o trabalho de Araújo e Santos (2012) que, embora não tenham se dedicado ao estudo empírico da questão, levantaram, por intermédio de pesquisa bibliográfica, causas de evasão no âmbito da Educação Profissional de nível médio, distinguindo fatores internos e externos às instituições escolares. Os primeiros, de acordo com a autora, estão relacionados à questão da escola não atrativa:

[...] de currículos desatualizados, da falta de apresentação do perfil do curso e de sua importância para o mercado, da falta de apresentação da demanda em empregabilidade na área do aluno, da falta de ações pedagógicas em disciplinas com altas taxas de retenção, da falta de apresentação coerente dos critérios e do sistema de avaliação do desempenho do aluno, da falta de formação didático pedagógica dos professores, de professor desmotivado, de poucas visitas técnicas, de pouca ou nenhuma aula prática, de pouca divulgação de vagas de estágio, da falta de parcerias e convênios com empresas para o estímulo da aprendizagem contextualizada, da falta de estágios e empregos aos alunos, da falta de adequação de plano de carreira do professor, da falta de estrutura na escola, da falta de laboratórios, de equipamentos de informática, de recursos humanos para apoio aos alunos, como psicólogos, assistentes sociais, orientadores educacionais, além de apoio e reforço para os alunos com dificuldades. Página 8.

Os fatores externos, por sua vez, remetem, principalmente, às questões vinculadas ao trabalho e envolvem desde os elementos relacionados à escolha da profissão e posicionamento no mercado até as dificuldades relativas à incompatibilidade de horários. Outro fator mencionado pelas autoras nesse grupo trata da ausência de políticas públicas consistentes e dificuldades na efetivação das políticas já existentes.

Para encerrar a análise aqui desenvolvida a respeito de abandono escolar na Educação Profissional, é imprescindível ressaltar um aspecto que, de maneira reflexiva ou não, permeia boa parte das pesquisas: o fato de ser este um fenômeno quase sempre vinculado à trajetória de estudantes economicamente desfavorecidos e pertencentes a grupos étnicos ainda discriminados. Muitos autores discorreram a respeito dessa questão e suas análises, de certo modo, coincidem com a visão de Arroyo (2012) quando discute o direito à escola presente nas lutas das classes populares. $\mathrm{O}$ autor se exprime da seguinte forma: 
Os movimentos sociais mostram que pouco sabemos sobre essas relações tão determinantes entre o direito ao lugar e à escola como garantia desse direito primeiro de todo ser humano: a vida boa, digna e justa. Como estão ausentes essas relações tão estreitas nas análises pedagógicas tão ilustradas. A escola na cultura popular é mais do que escola ou mais do que a concepção reducionista, ilustrada de escola, de ensino de qualidade. Vincular o direito à escola com o direito ao lugar que está nas trajetórias das crianças e adolescentes, dos jovens e adultos dos coletivos que chegam às escolas públicas das periferias e dos campos poderá dar maior centralidade social e política ao direito à escola/lugar de viver justo e digno (ARROYO, 2012, p. 249).

O "viver justo e digno" ressaltado pelo autor deve nortear as práticas escolares e possibilitar a construção de escola enquanto espaço de acolhimento aos sujeitos e suas identidades. Evasão nada mais é que do que um processo de exclusão, estejam ou não os excluídos cientes disso. Ela representa a negação não apenas das histórias de vida, mas das possibilidades reveladas pela aquisição do saber. Importante é estar ciente, no entanto, que enquanto a escola não for lugar de humanização, de aceitação do outro, problemáticas relacionadas ao fracasso escolar, tal como a evasão, estarão sempre na pauta de discussões que, embora relevantes, carregam consigo apenas o mérito da repetição e o alento da utopia.

\section{Metodologia}

Esta investigação, conforme Vergara (2009), constitui um estudo de caso, coadunando-se, ainda, com os princípios das pesquisas de campo e documental. Quanto à natureza dos dados, pode ser definida como qualitativa.

O estudo foi realizado na Unidade de Ensino Descentralizada de Petrópolis (UnED Petrópolis), integrante do Centro Federal de Educação Tecnológica Celso Suckow da Fonseca (Cefet/RJ). Abordou a realidade da evasão em um curso técnico e, de forma mais específica, a que ocorre na transição do primeiro para o segundo período do curso. As informações utilizadas são referentes aos anos de 2010, 2011 e 2012.

É importante ressaltar que se trata de um curso técnico semestral, realizado sob os parâmetros da concomitância externa, ou seja, o estudante cursa o Ensino Médio em uma instituição de sua escolha, no turno matutino ou noturno e, à tarde, realiza o curso técnico no Cefet, no espaço da referida unidade. Alunos que já tenham concluído o Ensino Médio também estão aptos. Para aqueles que realizam de maneira simultânea, enfatiza-se que a obtenção do diploma no curso técnico está vinculada à finalização e consequente diplomação no Ensino Médio. 
O levantamento de dados, realizado junto à Secretaria Acadêmica da Unidade, revelou que, no conjunto dos três anos englobados pela pesquisa, 89 alunos evadiram das turmas de primeiro período, o que representa $38,36 \%$ do total. A amostra selecionada para essa investigação, do tipo não probabilística e definida por critérios de acessibilidade e conveniência, foi de 12 indivíduos, dos quais apenas 10 efetivaram sua participação.

O instrumento de coleta de dados utilizado foi a entrevista semiaberta, que mesclou questões descritivas, explicativas ou causais, avaliativas, hipotéticas e categoriais (VERGARA, 2012a). A fim de garantir a veracidade das informações e preservar as sequências das conversas, as entrevistas foram gravadas.

No que diz respeito à organização, análise e interpretação dos dados, optou-se por definir uma metodologia que, sendo difundida entre pesquisadores de temáticas semelhantes, atendesse ao propósito de responder adequadamente à questão geral estabelecida por esse estudo. Partindo do pressuposto de que a evasão apresenta causas múltiplas e intrincadas, não perceptíveis facilmente por intermédio de uma percepção puramente objetiva, considerou-se que a técnica de análise qualitativa de conteúdo poderia contribuir de modo mais eficaz. $\mathrm{O}$ emparelhamento ou pattern-matching, que verifica correspondências entre um determinado arcabouço teórico e os dados resultantes da investigação, foi a estratégia de análise qualitativa adotada.

A análise de conteúdo é um método de investigação de material textual que tem como uma de suas características fundamentais a definição de categorias (FLICK, 2009). Embora tenha sua origem na prática da quantificação, a técnica pode definir-se tanto por abordagens quantitativas quanto qualitativas, sendo exigíveis, em ambos os casos, o estabelecimento de categorias (VERGARA, 2012b). Laville e Dionne (1999, p. 214) afirmam que a análise de conteúdo “[...] permite abordar uma grande diversidade de objetos de investigação: atitudes, valores, representações, mentalidades, ideologias, etc.”.

Sobre o indispensável processo de categorização, que envolve a definição do tipo de grade mais adequada ao estudo, vale ressaltar que a escolha foi pela do tipo misto, que mescla, no enquadramento dos resultados, categorias definidas a priori com outras incluídas ao longo do processo. Assim, foi possível integrar solidez, obtida pela utilização do referencial teórico, e a necessária flexibilidade.

Foram definidas ainda, conforme previsto pela técnica de análise de conteúdo, as unidades de registro e de contexto, as quais, respectivamente, auxiliam o 
pesquisador a recortar o texto em elementos completos de análise e compreender seu significado (BARDIN, 2011). A unidade de registro considerada mais adequada foi o tema e a de contexto o parágrafo.

A Figura fornece uma síntese do percurso da análise de conteúdo estabelecido nesse estudo.

\subsection{Limitações do método}

Quanto à metodologia da análise de conteúdo, que se fundamenta sobretudo na definição de categorias, é possível afirmar que uma das principais limitações está na possibilidade da geração de resultados banais, o que pode ocorrer em função de negligências durante o processo de construção da grade. Elementos relevantes não categorizados podem ser determinantes no tocante à qualidade dos achados (SILVERMAN, 2009).

Outra limitação importante está relacionada à perspectiva sobre causas de evasão adotada nesse estudo. A investigação considera apenas a ótica do estudante no que concerne à decisão do abandono, deixando de explorar a percepção dos docentes, familiares e de outros atores importantes no processo. Como ressaltado na revisão da literatura aqui efetuada, mudanças relacionadas à perspectiva de investigação do problema têm o potencial de alterar os resultados da pesquisa, uma vez que a atribuição de significados, atrelada às experiências dos indivíduos, constituem algo muito particular. De qualquer modo, isso não desqualifica os achados dessa pesquisa, uma vez que o importante, em última instância, é a busca de coerência entre o posicionamento metodológico e os objetivos estabelecidos.

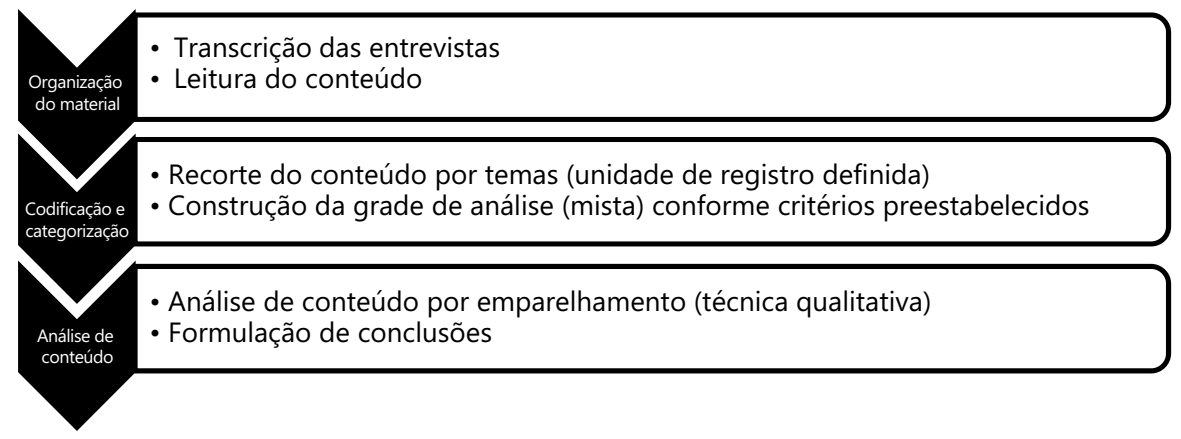

Fonte: Autoria própria (2014).

Figura. Processo de análise de conteúdo. 


\section{Resultados e discussão}

Tendo em vista a utilização da estratégia de análise de conteúdo, um dos procedimentos iniciais na exploração dos dados consistiu na categorização dos elementos que dizem respeito aos motivos pelos quais os alunos evadem. O Quadro 2 apresenta o resultado final desse procedimento, elencando as categorias e subcategorias que apontam as razões de evasão no curso abordado.

A análise a seguir está estruturada por conjunto de categoria e subcategorias conforme apresentado no Quadro 2. Os alunos evadidos estão identificados por códigos: A1 refere-se a aluno evadido 1, A2 refere-se a aluno evadido 2, e assim por diante.

\subsection{Escolha do curso}

Os fatores relacionados a essa categoria se vinculam às lacunas no processo de ingresso do aluno na Instituição que vão repercutir, associados a outros fatores, no abandono do curso. Enquadram-se aqui as seguintes subcategorias: ausência de informações, referente ao conhecimento prévio insuficiente das disciplinas e das possibilidades de atuação profissional; a decisão de ingresso vinculada à

Quadro 2. Categorização dos motivos de evasão no curso técnico analisado.

\begin{tabular}{|c|c|}
\hline \multirow{4}{*}{$\begin{array}{l}\text { Lacunas na escolha do } \\
\text { curso }\end{array}$} & Ausência de informações \\
\hline & Decisão de ingresso vinculada à experimentação \\
\hline & Ausência de maturidade \\
\hline & Não identificação \\
\hline \multirow{4}{*}{ Fatores escolares } & $\begin{array}{c}\text { Coincidência do período de provas (Curso Técnico e Ensino } \\
\text { Médio) e critérios de avaliação pouco flexíveis }\end{array}$ \\
\hline & Método pedagógico pouco dinâmico \\
\hline & Professores pouco incentivadores \\
\hline & Ausência de flexibilidade de horários \\
\hline \multirow{3}{*}{ Dificuldades pessoais } & Falta de conhecimento ou habilidade base \\
\hline & Conciliação do curso com o trabalho e/ou outros estudos \\
\hline & Sentimento de incapacidade e frustração \\
\hline Influência de amigos & Antecipação de experiências negativas \\
\hline Oportunidades & Oferta de trabalho e/ou outros estudos \\
\hline $\begin{array}{l}\text { Desinteresse institucional } \\
\text { e/ou governamental }\end{array}$ & Ausência de ações e/ou políticas de apoio à permanência \\
\hline
\end{tabular}

Fonte: Autoria própria (2014). 
experimentação, que ocorre como resultado da ausência de informações; a ausência de maturidade, expressa no fato de os alunos julgarem-se novos demais no momento do ingresso na Instituição; e a não identificação com o curso, seja no que se refere às disciplinas cursadas, seja no que diz respeito às possibilidades de atuação profissional.

As colocações do quadro 3 expressam problemas relacionados à escolha do curso.

A ausência de informações sobre o curso foi mencionada na pesquisa de Araújo e Santos (2012) enquanto um dos fatores internos motivadores de evasão. De acordo com as autoras, a falta de apresentação do perfil do curso e de sua relevância em termos de mercado agrega-se a um conjunto de fatores relacionados à não atratividade da escola.

A idade, associada aos processos de evasão, foi objeto de estudo de Stearns e Glennie (2006), embora não sob a perspectiva apontada por esses resultados. As autoras fizeram proposições a respeito das causas de abandono vinculadas a diferenças de idade, série, gênero e etnia, apontando probabilidades segundo as características de cada grupo. Em suas conclusões, relatam que estudantes mais jovens são mais propensos a deixarem a escola por razões disciplinares. Este estudo,

Quadro 3. Escolha do curso: transcrição de trechos de entrevistas.

\begin{tabular}{|c|c|}
\hline A9 & "Ah, Telecomunicações... deve ser legal! E entrei, não tinha nem noção de nada." \\
\hline A1 & $\begin{array}{c}\text { "Eu queria arriscar para ver se eu ia gostar da área e, quem sabe, me tornar assim } \\
\text { uma profissional [...] caso eu gostasse." }\end{array}$ \\
\hline \multirow{3}{*}{ A4 } & "Se eu não me engano, eu tinha 15 anos. Nem sabia o que eu queria de faculdade." \\
\hline & $\begin{array}{l}\text { "[...] conversei com a minha mãe. Minha mãe também falou pra mim: você tá muito } \\
\text { nova, tem que amadurecer suas ideias, o que você quer seguir, qual faculdade... e eu } \\
\text { fui florescendo isso na minha cabeça." }\end{array}$ \\
\hline & $\begin{array}{l}\text { "Eu acho que por eu estar muito nova, } 15 \text { anos... Telecomunicações, uma coisa } \\
\text { diferente, uma coisa que eu nunca tinha escutado falar. Eu acho que também pesou } \\
\text { um pouco." }\end{array}$ \\
\hline \multirow[t]{2}{*}{ A1 } & $\begin{array}{c}\text { "[...] conforme eu fui estudando as matérias, eu fui pensando assim: será que aquele } \\
\text { tipo de matéria, aquele tipo de exercício, eu ia querer seguir pra minha vida? Se } \\
\text { eu ia, por exemplo, terminar o curso e ia querer partir pra fazer uma faculdade de } \\
\text { Telecomunicação [...]. Eu percebi que não ia querer [...]" }\end{array}$ \\
\hline & "[...] eu achei a área muito interessante, mas pra mim... eu não trabalharia." \\
\hline A6 & $\begin{array}{l}\text { "[...] no desenvolver do curso [..] eu fui vendo que, tipo, não tinha muito a ver } \\
\text { comigo. [...] eu nunca, realmente, [...] gostei muito dessa área de Exatas." }\end{array}$ \\
\hline
\end{tabular}

Fonte: Autoria própria (2014). 
entretanto, desenvolvido a partir de uma abordagem diferenciada, pode sugerir a relação entre o fator idade e o abandono por não identificação com o curso.

A subcategoria "Não identificação com o Curso" figurou nas pesquisas de Silva e Dore (2011), que trouxeram reflexões a respeito do Programa de Educação Profissional de Minas Gerais (PEP-MG) e Cravo (2012), cujo objetivo foi investigar causas de evasão em um curso técnico de Informática. É interessante ressaltar, a respeito do PEP-MG, que o fator registrou uma frequência pouco significativa.

\subsection{Fatores escolares}

Os fatores escolares aparecem de forma bastante acentuada em muitos estudos sobre evasão. Embora, nessa pesquisa, tenha sido formulada apenas uma questão direta sobre o tema, as ocorrências foram registradas ao longo de diversos momentos dos discursos. Podem ser enquadradas aqui as seguintes subcategorias: coincidência do período de provas e critérios de avaliação pouco flexíveis, método pedagógico pouco dinâmico, professores pouco incentivadores e ausência de flexibilidade de horários.

A coincidência do período de provas e os critérios de avaliação pouco flexíveis dizem respeito, primeiramente, à dificuldade dos alunos em conciliar as rotinas de duas instituições, sobretudo no período de avaliações. Ter que realizar, por vezes, quatro ou mais provas em um único dia trazia como consequência muito mais do que esgotamento. Em segundo lugar, remete ao fato de os professores, em muitos casos, terem se utilizado da prova como único critério de avaliação, deixando de considerar as potencialidades dos alunos em sua totalidade.

O método pedagógico pouco dinâmico, nesse estudo, evidenciou problemas como: aulas excessivamente teóricas, material didático inadequado e estratégias pouco participativas. O elemento "Professores Pouco Incentivadores", por sua vez, vinculou-se à incapacidade de alguns professores de estimular os alunos no que tange tanto à permanência na Instituição quanto à aprendizagem. A última subcategoria, ausência de flexibilidade de horários, registrou as dificuldades relacionadas ao fato de o curso ser ministrado apenas no turno vespertino, o que se torna uma insatisfação, principalmente para os alunos que precisam dedicar parte de seu tempo ao trabalho.

O quadro 4 apresenta algumas colocações que explicitaram vínculos entre fatores escolares e o abandono do curso. 
Quadro 4. Fatores escolares: transcrição de trechos de entrevistas.

\begin{tabular}{|c|c|}
\hline A10 & $\begin{array}{c}\text { "[...] as provas do Cefet eram na mesma data das provas do colégio e ficava uma } \\
\text { coisa muito sobrecarregada. Eu falava assim: eu estudo pra quê? [...] Eu estudo pro } \\
\text { Cefet ou estudo pra escola?" }\end{array}$ \\
\hline A7 & $\begin{array}{l}\text { "[...] talvez o sistema de prova também mudasse um pouco, não fosse só: ah, você fez, } \\
\text { você passou, você foi aprovado. Eu acho que se essas coisas tivessem uma facilidade } \\
\text { maior [...] trabalho, comportamento... provas, que isso não tem como fugir." }\end{array}$ \\
\hline A3 & $\begin{array}{c}\text { "[...] Redes, assim... os materiais que o professor passava pra gente estudar } \\
\text { eram livros muito grandes e, fazendo junto com a escola - eu tava estudando } \\
\text { à noite - [...] era muita matéria." }\end{array}$ \\
\hline A4 & $\begin{array}{c}\text { "[...] o material didático [...] tem uns professores que falavam muito e eles colocavam } \\
\text { slide e tal... que eles tavam falando... só escrito. A gente não tinha, ali, a noção do } \\
\text { que a gente tava mexendo, a proporção daquilo. Então era só mais falado e [...] } \\
\text { esse método de ensino eu não gosto. [...] era questão, assim, de muita leitura. Eu } \\
\text { acho que fica mais interessante ter ali a coisa, no caso. [...] Porque eu, por exemplo, } \\
\text { aprendo muito com a prática. Eu prefiro, se eu pudesse dizer, mil vezes a prática do } \\
\text { que a aula teórica." }\end{array}$ \\
\hline \multirow{3}{*}{ A7 } & $\begin{array}{c}\text { "Bom, acredito que... não sei se todas são assim... você costuma ver isso muito na } \\
\text { faculdade, né? Que o aluno estando ali, estando ou não, tanto faz como tanto fez. } \\
\text { Então eu acho que, no técnico, o professor podia acreditar um pouco mais no aluno, } \\
\text { eu acho que nem sempre isso acontece." }\end{array}$ \\
\hline & $\begin{array}{c}\text { "[...] eu acho que faltou uma preocupação [...] porque teve situações que [...] você } \\
\text { via que podia ter feito algo mais por aquele aluno, mas o professor meio que ele se } \\
\text { anulou. Ah, não! Ele tirou isso aqui... é problema dele." }\end{array}$ \\
\hline & $\begin{array}{c}\text { "[...] tinha professores que eu via que chegavam a ser um pouco rude [...] porque já } \\
\text { estavam tão saturados de tá sempre chegando e chamando à atenção [...] você vai } \\
\text { vendo isso, você acaba se desmotivando." }\end{array}$ \\
\hline A7 & $\begin{array}{c}\text { "[...] acredito que teria que ter turmas à tarde pra pegar essas pessoas [o aluno } \\
\text { referiu-se aos estudantes adolescentes] e à noite pra, talvez... porque você vê que eu } \\
\text { entendi que a ideia do curso é pra quem tá no Ensino Médio, não pra quem já tá no } \\
\text { mercado de trabalho, pelo menos foi o que eu entendi." }\end{array}$ \\
\hline
\end{tabular}

Fonte: Autoria própria (2014).

Alguns autores refletiram acerca dos fatores escolares como causas de abandono. Sobretudo na educação do trabalhador, cabe a colocação de Costa (2000) quando afirma que, embora a escola brasileira pretenda, por intermédio da garantia de instrução básica a todos, alcançar o status de democrática, encontra obstáculos na própria incapacidade de constituir-se espaço efetivamente público, já que se revela incapaz de atender às necessidades de um aluno trabalhador em seu processo de aquisição de saberes.

No que diz respeito ao método pedagógico pouco dinâmico, Marin (1998) aponta para o despreparo profissional docente no que tange à organização de conteúdos e procedimentos didáticos, afirmando que esse constitui-se um dos elementos que concorrem para a produção do fracasso escolar. 
Sobre o elemento "Professores Pouco Incentivadores", subcategoria que trouxe como um de seus aspectos a questão das práticas pedagógicas culturalmente distantes do contexto de vida do aluno e de sua trajetória, cabe ressaltar o posicionamento de Setúbal (2010), quando discorre a respeito de interações sociais marcadas pelo que ela denomina "violência simbólica". A distância entre o currículo formal e a realidade do mundo dos estudantes, bem como a desvalorização de sua história e vivências é um exemplo de violência simbólica.

\subsection{Dificuldades pessoais}

As dificuldades pessoais, ao contrário do que se possa imaginar em um primeiro momento, não dizem respeito aos obstáculos cuja responsabilidade se possa atribuir aos estudantes evadidos. Enquadram-se aqui as subcategorias: falta de conhecimento ou habilidade base, conciliação do curso com o trabalho e/ou outros estudos e sentimento de incapacidade e frustração.

A falta de conhecimento ou habilidade base é um resultado típico nas pesquisas sobre evasão escolar. Diz respeito a lacunas em estudos anteriores ou mesmo concomitantes que dificultam, sobremaneira, o aprendizado do aluno, podendo referir-se, ainda, à ausência de habilidades que são importantes para a construção de conhecimentos em uma determinada área.

A dificuldade de conciliação entre as diversas atividades desenvolvidas pelos estudantes é também recorrente nas pesquisas sobre evasão. Esse fator, geralmente associado ao extremo cansaço e ao desempenho insatisfatório do estudante no curso e à queda das notas no Ensino Médio, encontra agravantes no ritmo corrido das aulas e na carga horária do curso, que alguns consideraram exaustiva.

O sentimento de incapacidade e a frustração, por sua vez, trata de questões mais íntimas, as quais surgem quando os estudantes se veem diante de dificuldades que parecem intransponíveis. Não raro, tais dificuldades estão associadas aos resultados insatisfatórios obtidos nas provas e às sucessivas reprovações.

Algumas das reflexões que ilustraram as dificuldades pessoais apresentadas nesse estudo estão dispostas no quadro 5.

A falta de base, associada às deficiências na formação escolar, também foi sinalizada como uma causa de abandono em Machado (2009), que analisou fatores motivadores de evasão nos cursos de Agropecuária e Informática da Escola Agrotécnica Federal de Inconfidentes. O que é importante ser discutido a esse 
Quadro 5. Dificuldades pessoais: transcrição de trechos de entrevistas.

\begin{tabular}{|c|c|}
\hline A3 & $\begin{array}{l}\text { "[...] no caso, no Ensino Fundamental, a gente não tem muito... a gente não tem } \\
\text { uma divisão assim... de Física, de Química. Aí, quando a gente chegou aqui [...] } \\
\text { a gente já entrou direto na matéria de elétrica, que é uma matéria bem mais } \\
\text { complicada, de Física [...] praticamente uma matéria de } 2^{\circ} \text { ou } 3^{\circ} \text { ano. Nessa } \\
\text { matéria, eu tive muita dificuldade. Eu lembro que eu tive nota baixa na P1, na P2..." }\end{array}$ \\
\hline \multirow[b]{2}{*}{ A3 } & $\begin{array}{c}\text { "[...] o ritmo das aulas era um pouco corrido [...] era um ritmo muito acelerado pra } \\
\text { quem tá fazendo o curso junto com a escola. [...] às vezes, a gente chegava a ter } \\
\text { assim... uma matéria nova por dia [...] não tinha assimilado o conteúdo anterior... } \\
\text { aí acumulava dúvida pro próximo conteúdo." }\end{array}$ \\
\hline & $\begin{array}{c}\text { "[...] a parte da manhã, geralmente, eu tirava pra... às vezes eu dormia até mais tarde. } \\
\text { Porque, como eu estudava à noite, eu chegava tarde em casa. [...] depois eu acordava } \\
\text { e tentava conciliar entre, nos dias que eu não tinha Inglês, estudar os conteúdos da } \\
\text { escola e estudar os conteúdos aqui, do Curso Técnico. Às vezes, até no caminho pra cá, } \\
\text { no ônibus, eu vinha estudando também, principalmente em dia de prova." }\end{array}$ \\
\hline \multirow{2}{*}{ A7 } & $\begin{array}{l}\text { "Só que aí você vê o resultado assim, você junta todas as suas coisas e aí fala: } \\
\text { realmente tem que trocar, um curso que dá pra se adaptar melhor, né?" }\end{array}$ \\
\hline & $\begin{array}{c}\text { "[...] Mas assim, você vê que, pro nível de exigência, eu não estava suficiente pra } \\
\text { continuar acompanhando." }\end{array}$ \\
\hline
\end{tabular}

Fonte: Autoria própria (2014).

respeito, entretanto, não é tratado em muitas pesquisas. Tem a ver com o fato de que falta de base, em uma análise mais ampla, é também questão de política pública. Se os alunos não dispõem dos conhecimentos básicos necessários ao acompanhamento das aulas, é porque, em muitos casos, são oriundos de escolas precarizadas, onde convivem com problemas que vão desde a ausência de infraestrutura básica para o aprendizado até a falta de professor ou de um ensino que possa lhes garantir condições mínimas de participação.

Considerando a atividade docente no processo de aprendizado do aluno dito "sem base", no entanto, é também importante ressaltar a responsabilidade profissional inerente, que coloca para o professor a necessidade de considerar um "ponto de partida" no planejamento e execução das aulas. Tendo em vista o objetivo precípuo da escola, o de possibilitar a aprendizagem, esse não é um ponto a ser ignorado. Dado o ingresso, ainda que em condições precárias, é papel docente e institucional criar condições para a aprendizagem, o que pressupõe, inclusive, articulação com a comunidade familiar.

A respeito da dificuldade discente na conciliação de múltiplas atividades, destacam-se as reflexões de Costa (2000, p. 11): 
No dia-a-dia, o estudante trabalhador enfrenta barreiras para sustentar a dupla jornada escola/trabalho, como a incompatibilidade parcial de horários, a fadiga física, os custos com transporte, a dificuldade de encontrar horários para cumprir os deveres escolares. Portanto, a opção pessoal é permeada por todas essas esferas da vida, de modo que não é uma decisão solitária como aparenta num primeiro momento. Ao analisar as histórias de evasão, depreendemos que o aluno abandona os estudos para fugir do conflito que representa a conciliação entre trabalho e escola, resistindo às injunções da disciplina do trabalho na escola, já que ao trabalho não pode deixar de ir. Acaba por aceitar o discurso de que ele próprio é o responsável solitário pelo seu fracasso escolar.

E ainda, no que se refere ao papel institucional nesse tipo de dificuldade, as de Machado (2009, p. 95):

Outra questão crucial, que surge nas pesquisas nacionais, referese ao excesso de conteúdo e à escassez de tempo para executá-los com a devida qualidade. As pressões para que os professores executem na totalidade os conteúdos planejados para aquela série leva-os, muitas vezes, a priorizar a quantidade em detrimento da qualidade $[\ldots]$.

Por fim, no que tange ao sentimento de incapacidade e frustração, é importante mencionar os achados de Doll, Eslami e Walters (2013), quando discorreram a respeito de um grupo de fatores responsáveis pelo abandono escolar denominado falling out. Conforme explicitado no tópico de revisão da literatura desse estudo, trata-se da dificuldade dos estudantes na demonstração de desempenho acadêmico satisfatório, o que poderia explicar atitudes de apatia e o sentimento de desilusão frente à possibilidade de conclusão dos estudos.

\subsection{Influência de amigos}

Essa categoria de abandono está relacionada ao maior ou menor grau de impacto das amizades na decisão do aluno de abandonar a escola. A influência de amigos é, frequentemente, imperceptível ao evadido, ou seja, quando solicitado a relatar as causas do seu abandono, esse fator dificilmente constará de sua análise. No entanto, o que se pôde observar é que, ainda que indiretamente, os amigos são sim capazes de reforçar a decisão de evasão, promovendo o que nesse estudo denominou-se "antecipação de experiências negativas". 
Alguns evadidos relataram se sentirem aflitos quanto aos obstáculos que enfrentariam a partir da conclusão do primeiro período. Esse sentimento provinha dos relatos de seus amigos que já cursavam o período subsequente e expressavam-se, constantemente, a respeito das dificuldades por eles vivenciadas. O quadro 6 expõe trechos de falas que favorecem essa análise.

$\mathrm{Na}$ análise da influência de amigos, cabem as reflexões de Carbonaro e Workman (2013). Os autores investigaram os efeitos das amizades próximas e distantes no comportamento de evasão e concluíram sobre a maior influência dos últimos. Esse fato curioso, segundo os autores, pode ser explicado pela constatação de que amizades distantes se tornam referência na construção da identidade social dos indivíduos, ditando aquilo que se constitui norma. Embora, talvez, não se possa enquadrar os amigos dos respondentes no âmbito das amizades distantes, é razoável pensar sobre o fato de que, sempre que se referiam aos amigos da turma na qual estavam inseridos (mais próximos), os evadidos remetiam-se a questões como apoio e trabalho cooperativo.

\subsection{Oportunidades}

Os fatores aqui enquadrados dizem respeito à atratividade de elementos externos na decisão do estudante de abandonar a Instituição. No contexto dessa pesquisa, a oferta de trabalho e/ou outros estudos constitui a subcategoria representativa.

Causa de abandono bastante frequente nas pesquisas sobre evasão, a oferta de trabalho e/ou outros estudos conduzem os estudantes a tomar decisões aparentemente impensadas, quase sempre pautadas na possibilidade de vantagens imediatas. Ainda que essa aparente ser uma razão bastante razoável para determinar, sozinha, a evasão do estudante, está associada a alguns outros fatores que se desdobraram ao longo da trajetória do aluno na Instituição. No momento

Quadro 6. Influência de amigos: transcrição de trechos de entrevistas.

\begin{tabular}{|c|c|}
\hline \multirow{4}{*}{ A4 } & $\begin{array}{c}\text { "Eu tava no primeiro e tinha amigos que tavam no segundo. Eles também falavam que } \\
\text { era bem puxado, muito puxado mesmo. Se você não conseguisse conciliar os dois..." }\end{array}$ \\
\cline { 2 - 3 } "Apavorou. Porque eu os via com um monte de folha e mais folha estudando pra \\
prova... e eu... meu Deus do Céu, aonde que..."
\end{tabular}

Fonte: Autoria própria (2014). 
em que a oportunidade aparece, os alunos refletem sobre uma série de razões que favorecem a sua não permanência e optam, certos de que fizeram a melhor escolha. Os trechos registrados no quadro 7 ilustram essa categoria de fatores de abandono.

A respondente 9 alegou, inicialmente, que havia abandonado o curso apenas pela proposta de emprego. Ao longo da entrevista, no entanto, foi pontuando diversos problemas que permearam sua trajetória na Instituição, tais como: não identificação com o curso, aulas pouco dinâmicas, dificuldades associadas à falta de conhecimento base, carga horária "puxada" e salas calorentas. Portanto, se for realizada uma análise mais criteriosa a respeito dos motivos que a conduziram ao abandono, será possível concluir que eles foram além do surgimento de uma oportunidade mais "vantajosa".

Entretanto, deixada de lado, por um momento, essa análise, é importante registrar que o surgimento de oportunidades, enquanto elemento motivador de evasão, foi enquadrado por Stearns e Glennie (2006) em uma categoria que elas denominaram fatores pull-out, que representam as razões de abandono externas às escolas. Esses fatores funcionam como elementos de atração dos alunos para fora das instituições e incidem de maneira distinta sobre diferentes perfis de estudantes.

\subsection{Desinteresse institucional e/ou governamental}

Trata-se de razões para o abandono que destacam a negligência da Instituição escolar e do próprio governo no resgate de alunos evadidos. À semelhança de outros fatores, não foram apontados pelos estudantes como causas diretas do abandono, mas perpassaram seus discursos de modo bastante reflexivo. O desinteresse institucional e/ou governamental é representado aqui pela ausência de ações e/ou políticas de apoio à permanência e expressou-se em afirmações como as dispostas no quadro 8 .

Quadro 7. Oportunidades: transcrição de trechos de entrevistas.

\begin{tabular}{|l|c|}
\hline A8 & $\begin{array}{c}\text { "[...] eu já estava em lista de espera pela Casa do Alemão pra conseguir uma bolsa } \\
\text { no Senai, que aí eu recebia o auxílio e tudo mais e fazia o curso. Aí eu acabei sendo } \\
\text { chamada [...] quando eles me chamaram eu dei preferência pra fazer o Senai porque } \\
\text { eu recebia. [...] como eu ficava o dia inteiro fora de casa, eu precisava de dinheiro." }\end{array}$ \\
\hline A9 & $\begin{array}{c}\text { "Na época, minha irmã já estudava aqui fazendo Turismo à noite. Então ela ficou } \\
\text { sabendo do curso e me avisou. Eu estudava só à noite e não trabalhava. Então } \\
\text { eu me interessei [...] eu me inscrevi no curso. Só que depois tive que parar porque } \\
\text { comecei a trabalhar." }\end{array}$ \\
\hline
\end{tabular}

Fonte: Autoria própria (2014). 
Quadro 8. Desinteresse institucional e/ou governamental: transcrição de trechos de entrevistas.

\begin{tabular}{|c|c|}
\hline $\mathrm{A} 2$ & $\begin{array}{c}\text { "[...] porque eu vejo, igual eu mesma... eu podia não estar fazendo nada agora, } \\
\text { eu podia estar trabalhando, não fazendo faculdade. Então eu ia ter perdido uma } \\
\text { oportunidade. Então eu acho assim: que o governo deveria correr atrás dessas } \\
\text { pessoas e ver o porquê elas desistiram. De repente, dar uma ajuda pra ver... porque } \\
\text { tem pessoas que não têm condições. [...] às vezes, a pessoa não tem condições de } \\
\text { bancar... [...] por exemplo, passagem [...] algumas coisinhas... tem gente que não tem } \\
\text { condições. [...] lá mesmo, na faculdade, tem várias pessoas que desistiram porque } \\
\text { não têm como bancar passagem. E ninguém vai... eles deixam, não se importam, } \\
\text { acham que não precisa." }\end{array}$ \\
\hline $\mathrm{A} 1$ & $\begin{array}{l}\text { "[...] Eu acho que devia aumentar essa questão de bolsas [...] bolsas mesmo em } \\
\text { colégios melhores, porque, infelizmente, colégio público... minha mãe sempre me } \\
\text { falou que quem faz o colégio são os alunos, mas mesmo assim... tem colégio que } \\
\text { não dá uma base muito boa pro aluno chegar num curso, por exemplo, no Cefet, } \\
\text { e conseguir acompanhar, conseguir entender as aulas. [...] eu estudei em colégio } \\
\text { público, mas eu tive uma educação decente num colégio público." }\end{array}$ \\
\hline A5 & $\begin{array}{c}\text { "O governo não só poderia investir na graduação e pós-graduações [...] poderia } \\
\text { investir melhor no fundamental e no médio, tanto é que escolas públicas municipais } \\
\text { e estaduais tem aquele declínio em comparação com as particulares. Poderia } \\
\text { investir mais na educação de base." }\end{array}$ \\
\hline A8 & $\begin{array}{c}\text { "[...] Eu acho que... não sei se hoje em dia tem... se o Cefet agisse como o Pronatec } \\
\text { age seria bem vantajoso. [...] A questão do lanche, a questão da passagem, } \\
\text { entendeu? Eles dão tudo isso lá." }\end{array}$ \\
\hline
\end{tabular}

Fonte: Autoria própria (2014).

As colocações dos respondentes não são desprovidas de sentido. Algumas dessas reflexões foram feitas por pesquisadores que buscaram também compreender os motivos pelos quais os alunos não concluem seus estudos nos cursos técnicos. Araújo e Santos (2012) ressaltaram a ausência de políticas públicas consistentes e a efetivação das políticas já existentes como um fator externo de evasão escolar na educação profissional de nível médio, alertando quanto ao número reduzido de projetos que têm por objetivo favorecer a permanência dos alunos nas instituições.

\section{Conclusão}

O objetivo principal dessa pesquisa consistiu em analisar as causas pelas quais os alunos abandonam o primeiro período de um curso técnico ofertado pela Unidade do Cefet/RJ situada em Petrópolis, tendo em vista tratar-se de um quantitativo expressivo de estudantes. Essa análise perpassou aspectos qualitativos relacionados aos motivos de evasão, não tendo sido meta, portanto, enumerar ou classificar as razões do abandono segundo a quantidade de estudantes que as mencionaram. Buscou-se, por intermédio de uma perspectiva mais reflexiva, captar 
os significados atribuídos pelos respondentes aos mais diversos elementos de seu percurso, investigando de que modo cada um dos fatores de evasão alegados se enquadrava no contexto.

Conforme demonstrado nessa pesquisa, a perda de alunos remete a aspectos que vão muito além daqueles considerados por uma análise de cunho meramente economicista. Evasão diz sim respeito aos prejuízos financeiros advindos da impossibilidade de manter os alunos em um determinado curso. Antes disso, porém, a temática insere-se no âmbito das discussões que nos levam a questionar o tipo de formação que vem sendo oferecida pelas escolas, sobretudo aquelas voltadas à formação do jovem trabalhador. Consta do Plano de Desenvolvimento Institucional do Cefet/RJ, enquanto um dos princípios norteadores da filosofia institucional, o seguinte: "Defesa das condições garantidoras de qualidade social para a educação pública viabilizada pela Rede Federal de Educação Profissional, Científica e Tecnológica em sua diversidade institucional" (CEFET/RJ, 2010, p. 10).

Deve-se ter em mente que a expressão qualidade social, no que se refere às práticas próprias de uma instituição escolar, confere um sentido à formação que extrapola aspectos facilmente quantificáveis, situando a educação em termos de sua ação política na sociedade. Entende-se, em um sentido amplo, que uma orientação de cunho emancipatório, capaz de fornecer aos alunos uma concepção verdadeiramente transformadora, tanto a nível individual quanto coletivo, torna-se não só desejável como necessária, sendo esse o princípio que deve nortear todas as ações que se desenvolvem no interior da escola. No entanto, só é possível defender as "condições garantidoras de qualidade social" se, em primeiro lugar, estivermos sensivelmente atentos à trajetória dos estudantes que ingressam na Instituição, o que implica um olhar cuidadoso sobre os alunos em risco iminente de evasão.

Pensar o tipo de formação oferecida, bem como estar "sensivelmente atento" à trajetória dos estudantes que ingressam na escola, tem a ver, é ressaltado, sobretudo com o papel do professor. É claro que a responsabilidade é institucional se observarmos que toda ação docente se dá em consonância com um projeto pedagógico que é coletivamente construído, cujo conteúdo expressa uma visão de educação pertencente à comunidade envolvida em sua construção. No entanto, é no cotidiano da sala de aula que relações são construídas, que os aprendizados mais importantes, sejam eles de natureza cognitiva, social ou moral, acontecem. Cabe ao professor, portanto, pensar o processo de ensino/aprendizagem a partir de uma perspectiva democrática, não excludente, valorizadora das histórias individuais e voltada, sobretudo, para o ser humano. 
Os resultados não apenas dessa pesquisa, como os de muitas outras a respeito da temática, têm revelado a insuficiência de esforços, oriundos das mais diversas esferas de atuação, no sentido de pensar projetos e desenvolver ações que favoreçam a permanência dos estudantes nos cursos. Sabe-se que não será sempre possível, a nível local, impedir o fenômeno da evasão, que, em última instância, tem suas origens na própria estrutura do sistema econômico em que estamos inseridos. Todavia, é não apenas viável, como urgente, ir além do que tem sido feito. Partindo de uma concepção de educação individualizada, que busca acompanhar a trajetória de cada estudante, é possível realizar um trabalho preventivo e também de resgate. O que não é mais admissível é cruzarmos os braços sempre que um aluno "some" da instituição, como se não fosse papel nosso garantir que ele também exerça seu direito de permanecer.

\section{Agradecimento}

Ao Cefet/RJ, por financiar o curso de Mestrado do qual derivou essa pesquisa. 


\title{
Professional Education and student dropout in context: reasons and reflections
}

\begin{abstract}
This research aimed to analyze the causes of dropout in the first period of a technical course of CEFET/RJ, Petrópolis Unit. The study sought not only to identify the factors directly signaled by former students as abandonment causes, but to understand the relationships between the various elements present in their speeches. The research, which involved desk and field research, took the form of a case study and was a qualitative study that employed the strategy of content analysis for treating the material, collected via slightly open interviews. The results show causes of evasion related to the following categories: gaps in choosing the course; school factors; personal difficulties; influence of friends; opportunities and institutional and/or governmental disinterest.
\end{abstract}

Keywords: Professional education. Technical course. Dropout.

\section{Educación Profesional y absentismo escolar en contexto: razones y reflexiones}

\section{Resumen}

Esta investigación tuvo como objetivo analizar las causas de la deserción escolar en el primer periodo de un curso técnico del CEFET / RJ, Unidad Petrópolis. Buscamos no solo identificar los factores directamente señalados por los alumnos como causa del abandono, sino la comprensión de las relaciones entre los diversos elementos presentes en sus discursos. La investigación, que involucró investigación documental y de campo, tomó la forma de un estudio de caso. En cuanto al enfoque del estudio, fue cualitativo y empleó la estrategia de análisis de contenido para el tratamiento de los materiales recogidos a través de entrevistas ligeramente abiertas. Los resultados de la investigación apuntaron como causas de evasión las relacionadas con las siguientes categorías: lagunas en la elección del curso; factores escolares; dificultades personales; influencia de los amigos; oportunidades y desinterés institucional y/o gubernamental.

Palabras clave: Educación profesional. Curso técnico. Evasión. 


\section{Referências}

ARAÚJO, C. F.; SANTOS, R. A. A educação profissional de nível médio e os fatores internos/externos às instituições que causam a evasão escolar. In: INTERNATIONAL CONGRESS ON UNIVERSITY - INDUSTRY COOPERATION, 4., Taubaté, 2012. Taubaté: Universidade de Taubaté, 2012. Disponível em: $<$ http://www.unitau.br/app/webroot/unindu/artigos/pdf525. pdf $>$. Acesso em: 26 jun. 2016.

ARAÚJO, E. J. M. Evasão no PROEJA: estudo das causas no Instituto Federal de Educação, Ciência e Tecnologia do maranhão/IFMA. Dissertação (Mestrado em Educação) - Programa de Pós-Graduação Stricto Sensu em Educação,Universidade Católica de Brasília, Brasília, DF, 2012.

ARROYO, M. G. Outros sujeitos, outras pedagogias. Petrópolis: Vozes, 2012.

AZEVEDO, C. P.; LIMA, E. S. A evasão escolar no PROEJA do CEFET-MT: existência e visão. Educação Profissional: Ciência e Tecnologia, v. 4, n. 2, p. $79-88$, abr. 2011.

BAGGI, C. A. S.; LOPES, D. A. Evasão e avaliação institucional no ensino superior: uma discussão bibliográfica. Avaliação (Campinas), v. 16, n. 2, p. 355-74, jul. 2011. http://doi.org/10.1590/S1414-40772011000200007

BARDIN, L. Análise de conteúdo. São Paulo: Edições 70, 2011.

BOWERS, A. J.; SPROTT, R. Examining the multiple trajectories associated with dropping out of high school: a growth mixture model analysis. Journal of Educational Research, v. 105, n. 3, p. 176-95, 2012.

BRASIL. Ministério da Educação. Centenário da rede Federal de Educação Profissional e Tecnológica. Brasília, DF, 2016. Disponível em: $<\mathrm{http}$ ://portal. mec.gov.br/setec/arquivos/centenario/historico_educacao_profissional.pdf $>$. Acesso em: 26 jun. 2016.

. Ministério da Educação. Instituto Nacional de Estudos e Pesquisas Educacionais Anísio Teixeira - INEP. Dicionário de indicadores educacionais: fórmulas de cálculo. Brasília, DF, 2004.

CARBONARO, W.; WORKMAN, J. Dropping out of high school: effects of close and distant friendships. Social Science Research, v. 42, n. 5, p. 1254-68, 2013. 
CENTRO FEDERAL DE EDUCAÇÃO TECNOLÓGICA CELSO SUCKOW DA FONSECA- RIO DE JANEIRO - CEFET/RJ. Plano de Desenvolvimento Institucional - PDI 2010/2014. Rio de Janeiro: Cefet/RJ, 2010.

COMISSÃO ESPECIAL DE ESTUDOS SOBRE A EVASÃO NAS UNIVERSIDADES PÚBLICAS BRASILEIRAS. Diplomação, retenção e evasão nos cursos de graduação em instituições de ensino superior públicas.. Brasília, DF, 1996. Disponível em: <http://www.andifes.org.br/ wp-content/files_flutter/Diplomacao_Retencao_Evasao_Graduacao_em_IES_ Publicas-1996.pdf>. Acesso em: 28 maio 2016.

COSTA, A. C. A "Escola-sacrifício": representações dos alunos sobre a escola, o processo escolarização, a evasão escolar e a conciliação escola/trabalho. Educação: Teoria e Prática, v. 8, n. 14/15, p. 8-14, 2000. http://doi.org/10.18675/1981-8106.vol1.n1.p08

CRAVO, A. C. Análise das causas da evasão escolar do curso técnico de informática em uma faculdade de tecnologia de Florianópolis. Revista Gestão Universitária na América Latina - GUAL, v. 5, n. 2, p. 238-250, ago. 2012. http://doi.org/10.5007/1983-4535.2012v5n2p238

DOLL, J. J.; ESLAMI, Z.; WALTERS, L. Understanding why students drop out of high school, according to their own reports: are they pushed or pulled, or do they fall out? A comparative analysis of seven nationally representative studies. SAGE Open, v. 3, n. 4, nov. 2013. http://doi.org/10.1177/21582440135033834

DORE, R.; LÜSCHER, A. Z. Permanência e evasão na educação técnica de nível médio em Minas Gerais. Cadernos de Pesquisa, v. 41, n. 144, p. 770-89, dez. 2011. http://doi.org/10.1590/S0100-15742011000300007

FALL, A.M.; ROBERTS, G. High school dropouts: Interactions between social context, self-perceptions, school engagement, and student dropout. Journal of Adolescence, v. 35, n. 4, p. 787-98, ago. 2012. http://doi.org/10.1016/j.adolescence.2011.11.004

FLICK, U. Uma introdução à pesquisa qualitativa. 3. ed. Porto Alegre: Bookman, 2009.

FORNARI, L. T. Reflexões acerca da reprovação e evasão escolar e os determinantes do capital. Revista Espaço Pedagógico, v. 17, n. 1, p. 112-124, 2010. 
FREDENHAGEM, S. et al. A voz da evasão. Revista EIXO, v. 1, n. 2, p. 2-19, dez. 2012. http://doi.org/10.19123/eixo.v1i2.51

HOFFMANN, J. Avaliação: mito \& desafio, uma perspectiva construtivista. 43. ed. Porto Alegre: Mediação, 2013.

\section{INSTITUTO NACIONAL DE ESTUDOS E PESQUICAS} EDUCACIONAIS ANÍSIO TEIXEIRA - INEP. Projeto: Educação Profissional no Brasil e evasão escolar. Disponível em: $<$ http://portal.inep. gov.br/web/observatorio-da-educacao/visualizar/-/asset_publisher/La44/ content/projeto\%3A-educacao-profissional-no-brasil-e-evasao-escolar?re direct=http $\% 3 \mathrm{~A} \% 2 \mathrm{~F} \% 2 \mathrm{Fportal}$.inep.gov.br\%2Fweb\%2Fobservatorio-daeducacao\%2Fnucleo-unico>. Acesso em: 6 jan. 2014.

JOHANN, C. C. Evasão escolar no Instituto Federal Sul-Rio-Grandense: um estudo de caso no campus Passo Fundo. Dissertação (Mestrado em Educação) - Universidade de Passo Fundo, Passo Fundo, 2012.

LAVILLE, C.; DIONNE, J. A construção do saber: manual de metodologia da pesquisa em ciências humanas. Porto Alegre: Artmed, 1999.

LEE, V. E. .; BURKAM, D. T. Dropping out of high school: the role of school organization and structure. American Educational Research Journal, v. 40, n. 2, p. 353-93, 2003.

MACHADO, M. R. A evasão nos cursos de agropecuária e informática / nível técnico da escola agrotécnica federal de Inconfidentes - MG (2002 a 2006). Dissertação (Mestrado Profissional em Educação) - Faculdade de Educação, Universidade de Brasília, Brasília, 2009.

MACHADO, M. R. L.; MOREIRA, P. R. Educação profissional no Brasil, evasão escolar e transição para o mundo do trabalho. In: SEMINÁRIO NACIONAL DE EDUCAÇÃO PROFISSIONAL E TECNOLÓGICA, 3., 2012, Belo Horizonte. Anais... Belo Horizonte: Cefet-MG, 2012. Disponível em: $<$ http://www.senept.cefetmg.br/galerias/Arquivos_senept/anais/terca_ tema3/TerxaTema3Poster9.pdf>. Acesso em: 26 jun. 2016.

MARCONATTO, L. J. A evasão escolar no curso de técnico agrícola na modalidade de EJA da EAF Rio do Sul - SC. Dissertação (Mestrado em Educação Agrícola) - Instituto de Agronomia, Universidade Federal Rural do Rio de Janeiro, Rio de Janeiro, 2009. 
MARIN, A. J. Com o olhar nos professores: desafios para o enfrentamento das realidades escolares. Cadernos CEDES, v. 19, n. 44, p. 8-18, 1998. http://doi.org/10.1590/S0101-32621998000100002

MOREIRA, P. R. Evasão escolar nos cursos técnicos do PROEJA na rede Federal de Educação Profissional e Tecnológica de Minas Gerais. Dissertação (Mestrado em Educação) - Faculdade de Educação,Universidade Federal de Minas Gerais, Belo Horizonte, 2012.

MURNANE, R. J. U.S. high school graduation rates: patterns and explanations. Journal of Economic Literature, v. 51, n. 2, p. 370-422, 2013.

NERI, M. (Coord.). Motivos da evasão escolar. 2010. Disponível em: $<\mathrm{http}: / /$ www.cps.fgv.br/ibrecps/TPE/TPE_MotivacoesEscolares_fim.pdf $>$. Acesso em: 26 jun. 2016.

OLIVEIRA, M. A. M. A reforma do ensino profissional: desmantelamento da educação tecnológica ministrada pelo Cefet-X? Educação Brasileira, v. 23, n. 46, p. 25-43, jun. 2001.

RUMBERGER, R. W. Dropping out of middle school: a multilevel analysis of students and schools. American Educational Research Journal, v. 32, n. 3, p. 583-625, 1995. http://doi.org/10.3102/00028312032003583

. Introduction. In: DROPPING out: why students drop out of high school and what can be done about it. Cambridge, Mass: Harvard University Press, 2011. p. 1-19.

SALES, P. E. N.; CASTRO, T. L.; DORE, R. Educação profissional e evasão escolar: estudo e resultado parcial de pesquisa sobre a rede federal de educação profissional e tecnológica de Minas Gerais. In: COLÓQUIO INTERNACIONAL SOBRE EDUCAÇÃO PROFISSIONAL E EVASÃO ESCOLAR, 3., 2013, Belo Horizonte. Belo Horizonte: Rimepes, 2013.

SETÚBAL, M. A. Equidade e desempenho escolar: é possível alcançar uma educação de qualidade para todos? Revista Brasileira de Estudos Pedagógicos, v. 91, n. 228, p. 345-66, 2010.

SILVA, M. R.; PELISSARI, L. B.; STEIMBACH, A. A. Juventude, escola e trabalho: permanência e abandono na educação profissional técnica de nível médio. Educação e Pesquisa, v. 39, n. 2, p. 403-17, jun. 2013. 
SILVA, W. A.; DORE, R. O Programa de Educação Profissional de Minas Gerais e a evasão escolar: um estudo preliminar (2008-2010). Educação em Foco, v. 14, n. 18, p. 75-95, 2011.

SILVERMAN, D. Interpretação de dados qualitativos: métodos para análise de entrevistas, textos e interações. 3. ed. Porto Alegre: Artmed, 2009.

STEARNS, E.; GLENNIE, E. J. When and why dropouts leave high school. Youth \& Society, v. 38, n. 1, p. 29-57, set. 2006. http://doi.org/10.1177/0044118X05282764

VERGARA, S. C. Métodos de coleta de dados no campo. 2. ed. São Paulo: Atlas, 2012a.

. Métodos de pesquisa em administração. 5. ed. São Paulo: Atlas, 2012b. . Projetos e relatórios de pesquisa em administração. 10. ed. São

Paulo: Atlas, 2009.

\section{Informações das autoras}

Natália Gomes da Silva Figueiredo: Mestre em Sistemas de Gestão pela Universidade Federal Fluminense. Pedagoga no Centro Federal de Educação Tecnológica Celso Suckow da Fonseca. Contato: natalia.figueiredo@cefet-rj.br

Denise Medeiros Ribeiro Salles: Doutora em Administração pela Fundação Getúlio Vargas. Professora adjunta na Universidade Federal Fluminense - UFF. Pesquisadora do Programa de Pós-Graduação em Administração da UFF. Contato: denisesalles@id.uff.br 